\title{
Genetics of phosphorus content in common bean seeds
}

Nerinéia Dalfollo Ribeiro ${ }^{1}$, Simone Saydelles da Rosa ${ }^{1}$, Evandro Jost ${ }^{1}$, Daniele Piano Rosa ${ }^{1}$, Nerison Luís Poersch ${ }^{1}$ and Sandra Maria Maziero ${ }^{1}$

Received 23 January 2010

Accepted 30 September 2010

\begin{abstract}
The common bean is an important source of minerals and protein in human nutrition. The objective of this study was to investigate possible maternal effects on phosphorus contents in seeds of the common bean, to estimate the heritability in early hybrid generations for the phosphorus content character and to evaluate the potential for genetic improvement. The controlled crossings were performed among Pérola x Guapo Brilhante and TPS Nobre x Guapo Brilhante cultivars. Reciprocal $F_{1}$, and $F_{2}$ generations as well as backcross populations were produced by each hybrid combination. The range of variation in phosphorus content among tested progenies was from 3.38 to $5.78 \mathrm{~g} \mathrm{~kg}^{-1}$ dry matter, and no significant maternal effect was discovered. Narrow sense heritability was of an intermediate $65.54 \%$ to low $21.37 \%$ value. An increase of $19.17 \%$ was obtained for phosphorus content in the seeds using just the three parents tested in this study.
\end{abstract}

Key words: Phaseolus vulgaris L., maternal effect, heritability, early generation.

\section{INTRODUCTION}

Phosphorous is a mineral present in practically all foods and their deficiency is rare (Fennema 2000). However, when phosphorous deficiency is diagnosed in the human organism, it has been observed to cause neuromuscular, skeletal, hematological and renal abnormalities (Kathleen 1998). Phosphorous also plays a part in energy metabolism, since it is a constituent of adenosine triphosphate (ATP) and is therefore important in absorbing and transporting nutrients, in regulating protein activity and in the acidbase balance (Cozzolino 2007). For this reason, 0.8 to $1.2 \mathrm{~g}$ phosphorous is recommended, according to age, to supply the daily requirements for an adult (Kathleen 1998).

The common bean (Phaseolus vulgaris L.) has a high seed phosphorous content (Beebe et al. 2000, Mesquita et al. 2007) and genetic variability has been observed for phosphorous content character. Accessions with the range of variation from 3.60 to $6.55 \mathrm{~g} \mathrm{~kg}^{-1}$ dry matter (DM) were tested in Burundi (Barampama and Simard 1993) and from 5.86 to $8.84 \mathrm{~g} \mathrm{~kg}^{-1} \mathrm{DM}$ in Colombia (House et al. 2002). In Brazil, values ranging from 4.50 to $7.30 \mathrm{~g} \mathrm{~kg}^{-1} \mathrm{DM}$ were observed among 21 common bean genotypes in the Middle American gene pool (Mesquita et al. 2007). Common bean seeds from the Middle American gene pool normally present a higher phosphorous content in comparison with seeds of the Andean gene pool (Islam et al. 2002). The existence of genetic variability showed that selection is possible for the common bean germplasm with a high phosphorous content for diet enrichment. Another advantage in that its genotypes with high seed phosphorous contents also have an increase in grain yield (Silva et al. 2003).

The phosphorus content in seeds/grain can be increased by applying fertilizer to the soil (Silva and Vahl 2002) or by treating the seeds with $\mathrm{P}_{2} \mathrm{O}_{5}$ (Silva et al. 2003). However, other alternatives should be considered, since

\footnotetext{
${ }^{1}$ Universidade Federal de Santa Maria, Departamento de Fitotecnia, 97.105-900, Santa Maria, RS, Brasil. *E-mail: nerineia@ hotmail.com
} 
phosphorous is a non-renewable natural resource and, in Brazil, there are extensive areas of soils with low phosphorous availability and high capacity for retaining this mineral (Sfredo et al. 1997). Bearing this in mind, using genetic improvement to increase phosphorous content in common bean seeds is a low-cost option with significant social benefits, since 8 to $27 \%$ of the phosphorous necessary to satisfy daily nutritional requirements in Latin America is obtained through the consumption of beans (Pennington and Young 1990).

The common bean seed is made up of the seed-coat, representing around $9 \%$ dry matter, cotyledons at $90 \%$ of total dry matter, and the embryonic axis at only $1 \%$ of the total dry matter. The seed-coat contains more than $80 \%$ of the entire calcium content and only 1.9 to $3.6 \%$ of the phosphorus content (Moraghan et al. 2002). Hen ce, most phosphorus is in cotyledons. However, as the seed-coat represents maternal tissue (as opposed to the zygotic tissue of the cotyledons and the embryo), significant maternal effect are possible. Such an effect was observed in common bean seeds for the calcium content (Jost et al. 2009a). From the genetic point of view, the seed-coat and the embryo/ cotyledons are tissues that represent different generations and the expression of the genotype is delayed by one generation (Ramalho et al. 2008).

No significant maternal effect was discovered for insoluble dietary fiber content in common bean seeds (Londero et al. 2009). For this reason, selection for high insoluble dietary fiber content in the common bean should begin on the $\mathrm{F}_{2}$ seeds (cotyledons in $\mathrm{F}_{2}$ generation). This observation alone has direct implications on the selection process and the progression of segregating populations in genetic improvement programs.

It was postulated that the zinc content in the navy bean seeds was controlled by a single dominant allele and additive gene action was responsible for most of the observed (Cichy et al. 2005). In this case, a dominant monogenic inheritance and high heritability for zinc content was verified. To phosphorus content in common bean seeds no genetic study has been described.

No maternal effects has been investigate on the expression of the phosphorus content in the common bean seeds and there is some doubt as to whether the phosphorus content presents qualitative or quantitative inheritance. This study was designed to investigate possible maternal effects on the expression of the phosphorus content, to estimate the heritability of the character and selection gains, and to evaluate the potential for genetic improvement in high phosphorus common bean cultivars from the Middle American gene pool.

\section{MATERIAL AND METHODS}

Parents were selected based on their seed phosphorous content and agronomic value from among the accessions of the common bean maintained in the Bean Germplasm Bank of Santa Maria Federal University (UFSM), Brazil. The pattern of inheritance, including any possible maternal effects, was studied in hybrids obtained from the following crosses between three cultivars in the Middle American gene pool in: cv. Pérola $x$ Guapo Brilhante and TPS Nobre $x$ Guapo Brilhante. Pérola represented the Carioca type seeds (beige with brown streaks) and has an indeterminate growth habit with long guides (type III). Guapo Brilhante and TPS Nobre cultivars belonged to the black commercial group and have an indeterminate growth habit with a small to medium guide development (type II).

The crosses were made in a greenhouse, with emasculation of the flower bud using the interlacing method (Peternelli and Borém 1999). The $\mathrm{F}_{1}\left(\mathrm{P}_{1}\right.$ \% $\left.\mathrm{x} \mathrm{P}_{2} \sigma^{7}\right)$ and $\mathrm{F}_{1}$ reciprocal $\left(\mathrm{P}_{2}+\mathrm{x}_{1} \mathrm{\sigma}^{\mathrm{r}}\right)$ seeds were produced for each hybrid combination in autumn-winter 2007. In springsummer 2007, natural self-fertilization of $F_{1}$ hybrids produced reciprocal $\mathrm{F}_{2}$ generations, while backcrossing of $\mathrm{F}_{1}(q)$ to $\mathrm{P}_{1}\left(\mathrm{BCP}_{1}\right)$ and $\mathrm{F}_{1}(q)$ to $\mathrm{P}_{2}\left(\mathrm{BCP}_{2}\right)$ produced the backcross generations. The process was replicated in autumn-winter 2008, so that the seeds of the $F_{1}, F_{1}$ reciprocal, $\mathrm{F}_{2}, \mathrm{~F}_{2}$ reciprocal and backcross $\left(\mathrm{BCP}_{1}\right.$ and $\left.\mathrm{BCP}_{2}\right)$ generations could be evaluated under the same cultivation conditions.

In all stages, the seeds were sown in 5 liter capacity plastic pots in a mix of soil + Plantmax $®$ commercial substrate + carbonized rice husk, mixed in proportions 3: 1: 1 . The soil was typical alitic Argisol (Argissolo Bruno-Acinzentado), with the following chemical composition: $\mathrm{pH}\left(\mathrm{H}_{2} \mathrm{O}\right)$ : 5.8; organic matter: $1.9 \%$; zinc: $15.3 \mathrm{mg} \mathrm{dm}^{-3}$; potassium: 84 mg dm${ }^{-3}$; calcium: $5.8 \mathrm{cmol}_{\mathrm{c}} \mathrm{dm}^{-3}$; magnesium: $2.4 \mathrm{cmol}_{\mathrm{c}}$ $\mathrm{dm}^{-3}$; sulfur: $11.6 \mathrm{mg} \mathrm{dm}^{-3}$. Fertility was corrected in accordance with the chemical soil analysis. Plants were watered daily to maintain the soil water contents close to the field capacity. Diseases and insects were controlled as necessary in order to avoid compromising the normal development of the common bean plants and to maintain the integrity of the flower buds.

The pods were harvested at maturity and the seeds were removed manually. The seeds were dried in a greenhouse $\left(65-70{ }^{\circ} \mathrm{C}\right)$ until the average moisture content of $13 \%$. 
Samples of dry seeds were ground in a micro-mill to the particle size of less than $1 \mathrm{~mm}$. The phosphorous content of the raw bean flour was determined by nitric-perchloric digestion $\left(\mathrm{HNO}_{3}+\mathrm{HClO}_{4}\right.$, in proportion 3:1), as described by Miyazawa et al. (1999). The phosphorous content was measured using a UV-VIS spectrophotometer set to the wavelength of $660 \mathrm{~nm}$.

The experiments were run in a randomized complete block design with five replications for the parents and the reciprocal $F_{1}$ generations, and in 24 replications for the reciprocal $F_{2}$ generations. To test the maternal effect hypothesis, a comparison was made between the means using the $t$-test at the $5 \%$ significance level for contrasts $\mathrm{P}_{1}$ vs $\mathrm{P}_{2}, \mathrm{P}_{1}$ vs $\mathrm{F}_{1}, \mathrm{P}_{2}$ vs $\mathrm{F}_{1}$ reciprocal, $\mathrm{F}_{1}$ vs $\mathrm{F}_{1}$ reciprocal and $\mathrm{F}_{2} v s \mathrm{~F}_{2}$ reciprocal.

Estimates of the genetic parameters were obtained with the variances of parents $\mathrm{P}_{1}$ and $\mathrm{P}_{2}$ and $\mathrm{F}_{1}, \mathrm{~F}_{2}, \mathrm{BCP}_{1}$ and $\mathrm{BCP}_{2}$ generations, based on the generation of cotyledons, for each hybrid combination. The broad-sense heritability

$$
\mathrm{h}_{\mathrm{a}}^{2}=\frac{\sigma_{\mathrm{g}}^{2}}{\sigma_{\mathrm{P}}^{2}}
$$

and the narrow-sense heritability

$$
h_{\mathrm{r}}^{2}=\frac{\sigma_{\mathrm{A}}^{2}}{\sigma_{\mathrm{P}}^{2}}
$$

were estimated using the backcross method (Warner 1952).

Heterosis in the $F_{1}$ generation was quantified as a percentage, for both heterosis relative to the mean for the parents

$$
\mathrm{H} \%=\frac{\mathrm{F}_{1}-\mathrm{P}}{\mathrm{P}} \times 100
$$

and for heterobeltiosis

$$
\mathrm{HT} \%=\frac{\mathrm{F}_{1}-\mathrm{MP}}{\mathrm{MP}} \times 100
$$

where

$$
\mathrm{P}=\frac{\mathrm{P}_{1}+\mathrm{P}_{2}}{2}
$$

and $\mathrm{MP}=$ best male parent. For predicting selection gains, we took a selection of $25 \%$ of plants with $\mathrm{F}_{2}$ seeds (cotyledons in $\mathrm{F}_{2}$ generation) with the highest phosphorus content. The gain expected, taking into account selection and recombination of superior plants with $\mathrm{F}_{2}$ seeds (cotyledons in the $\mathrm{F}_{2}$ generation), was estimated using the formula: $\Delta \mathrm{G}+\mathrm{DSxh}_{\mathrm{r}}^{2}$ and

$$
\Delta \mathrm{G}(\%)=\frac{\Delta \mathrm{Gx} 100}{\overline{\mathrm{F}}_{2}}
$$

where is the selection differential expressed by $\overline{\mathrm{X}}_{\mathrm{s}}-\overline{\mathrm{X}}_{0}$, where $\bar{X}_{\mathrm{s}}=$ average of selected plants with seeds in $\mathrm{F}_{2}$ and $\bar{X}_{0}=$ average of plants with seeds in $\mathrm{F}_{2}$. Genetic-statistical analyses were carried out using the software Genes (Cruz 2006).

\section{RESULTS AND DISCUSSION}

In reciprocal hybrids Pérola $\left(\mathrm{P}_{1}: 4.15 \mathrm{~g} \mathrm{~kg}^{-1}\right.$ dry weight - DW) x Guapo Brilhante $\left(\mathrm{P}_{2}: 4.85 \mathrm{~g} \mathrm{~kg}^{-1} \mathrm{DW}\right)$ and TPS Nobre $\left(\mathrm{P}_{3}: 4.16 \mathrm{~g} \mathrm{~kg}^{-1} \mathrm{DW}\right)$ x Guapo Brilhante $\left(\mathrm{P}_{2}: 4.85 \mathrm{~g} \mathrm{~kg}^{-1}\right.$ DW) the contrast $P_{1}$ vs $P_{2}$ was significant, demonstrating a genetic difference between the parents in phosphorus content (Table 1).

No significant difference was observed between reciprocal $F_{1}$ hybrids suggesting no significant maternal effect for phosphorus content in common bean seeds (Table 1). The common bean seed phosphorus content is dependent on the cotyledons, products of fertilization. This occurs because in common bean seeds more the $96 \%$ phosphorus is concentrated in the embryo (cotyledons and embryonic axis) (Moraghan et al. 2002).

No significant difference was observed for the $\mathrm{F}_{2} v s$ $\mathrm{F}_{2}$ reciprocal contrast, reinforcing that the phenotype these seeds were similar in terms of phosphorus content and represented the expression of the genotype $\mathrm{F}_{1}$ generation. Therefore, $\mathrm{F}_{2}$ seeds showed embryo in the $\mathrm{F}_{2}$ generation. For this reason, selection for high phosphorus content in the common bean seeds should begin on the $\mathrm{F}_{2}$ seeds (cotyledons in $\mathrm{F}_{2}$ generation), since ample genetic variability was observed in this generation. To dietary fiber content in the common bean seeds no significant maternal effect was discovered, therefore the selection the $F_{2}$ seeds, harvested the one plant, was efficient (Londero et al. 2009).

However, significant maternal effect was observed for the calcium (Jost et al. 2009a) and iron content in common bean seeds (Jost et al. 2009b). Since calcium and iron contents were dependent on the seed-coat, selection was begun only on the $\mathrm{F}_{3}$ seeds (cotyledons in $\mathrm{F}_{2}$ generation), when segregation was verified. Therefore, investigation of the existence of maternal effect for characters that confer nutritional and functional quality for the common bean was appropriate, since it will have direct implications on the selection process and the progression of segregating populations in improvement programs.

Phosphorus content ranged from $3.38 \mathrm{~g} \mathrm{~kg}^{-1} \mathrm{DM}\left(\mathrm{F}_{2}\right.$ plant from Pérola x Guapo Brilhante hybrid) to $5.78 \mathrm{~g} \mathrm{~kg}^{-1}$ $\mathrm{DM}\left(\mathrm{F}_{2}\right.$ plant from TPS Nobre $\mathrm{x}$ Guapo Brilhante hybrid) 
Table 1. Mean phosphorus content and respective standard deviations obtained in parents $\left(P_{1}\right.$ and $\left.P_{2}\right)$ and in $F_{1}, F_{1}$ reciprocal, $F_{2}$ and $F_{2}$ reciprocal generations in Pérola $\mathrm{x}$ Guapo Brilhante and TPS Nobre $\mathrm{x}$ Guapo Brilhante hybrids and probability by the $t$-test for contrasts $\mathrm{P}_{1}$ vs $\mathrm{P}_{2}, \mathrm{P}_{1}$ vs $\mathrm{F}_{1}, \mathrm{P}_{2}$ vs $\mathrm{F}_{1}$ reciprocal, $\mathrm{F}_{1}$ vs $\mathrm{F}_{1}$ reciprocal and $\mathrm{F}_{2}$ vs $\mathrm{F}_{2}$ reciprocal

\begin{tabular}{lcc}
\hline \multirow{2}{*}{ Parents and Generation } & \multicolumn{2}{c}{ Phosphorus content $\mathbf{~ g ~ k g ~}^{-1}$ of DM) } \\
\cline { 2 - 3 } & Pérola x Guapo Brilhante & TPS Nobre x Guapo Brilhante \\
\hline $\mathrm{P}_{1}$ & $4.15 \pm 0.15$ & $4.16 \pm 0.32$ \\
$\mathrm{P}_{2}$ & $4.85 \pm 0.20$ & $4.85 \pm 0.20$ \\
$\mathrm{~F}_{1}$ & $4.80 \pm 0.24$ & $4.47 \pm 0.41$ \\
$\mathrm{~F}_{1}$ reciprocal & $4.59 \pm 0.25$ & $4.48 \pm 0.22$ \\
$\mathrm{~F}_{2}$ & $4.22 \pm 0.48$ & $4.68 \pm 0.51$ \\
$\mathrm{~F}_{2}$ reciprocal & $4.31 \pm 0.53$ & $4.26 \pm 0.46$ \\
Contrasts & & \\
$\mathrm{P}_{1}$ vs $\mathrm{P}_{2}$ & $0.03^{*}$ & $0.36^{*}$ \\
$\mathrm{P}_{1}$ vs $\mathrm{F}_{1}$ & $0.10^{*}$ & 53.43 \\
$\mathrm{P}_{2}$ vs $\mathrm{F}_{1}$ reciprocal & 11.19 & $2.39^{*}$ \\
$\mathrm{~F}_{1}$ vs $\mathrm{F}_{1}$ reciprocal & 21.52 & 98.09 \\
$\mathrm{~F}_{2}$ vs $\mathrm{F}_{2}$ reciprocal & 56.28 & $0.43^{*}$ \\
\hline
\end{tabular}

* Significant at 0.05 probability by the $t$-test.

(Table 2). Similar values were obtained in the common bean genotypes evaluated in Burundi (Barampama and Simard 1993). Higher values were observed in the evaluation of accessions cultivated in Brazil (Mesquita et al. 2007) and Colombia (House et al. 2002). As the common bean seeds from the Middle American gene pool present higher phosphorous content in comparison with seeds of the Andean gene pool (Islam et al. 2002), the concentration ranged in the germplasm.

Transgressive segregation was observed in both hybrid combinations (Table 2). Among the $\mathrm{F}_{2}$ plants examined, individuals with $5.78 \mathrm{~g} \mathrm{~kg}^{-1} \mathrm{DM}$ were identified, which represented an increase of $19.17 \%$ in phosphorus content relative to the Guapo Brilhante parent (4.85 $\mathrm{g} \mathrm{kg}^{-1} \mathrm{DM}$ ). This was the first register of increased phosphorus content in the common bean seeds by genetic improvement. A similar result was obtained by zinc content in common bean seeds (Gelin et al. 2007, Blair et al. 2009).

A breakdown of phenotypic variance showed the predominance of genetic effects in relation to the environment in the Pérola x Guapo Brilhante hybrid, and a high broadsense $\left(\mathrm{h}_{\mathrm{a}}^{2}=82.69 \%\right)$ and intermediate narrow-sense $\left(\mathrm{h}_{\mathrm{r}}^{2}=65.54 \%\right)$ heritability were observed. In this hybrid combination the additive variance constituted the higher fraction of the genetic variance, then the fixation of this character could be observed in advanced generations. In the improvement of autogamous plants, additive variance is of great importance since it does not segregate from generation to generation, making it possible to successfully select it in segregating populations, since the selective gains will depend only on gametic variance (Carvalho et al. 2001). For this reason Pedigree or Single-Seed Descent (SSD) methods are recommended for progression of segregating populations. Therefore, in the TPS Nobre $\mathrm{x}$ Guapo Brilhante hybrid, we verified heritability estimates for broad-sense heritability of an intermediate magnitude $\left(\mathrm{h}_{\mathrm{r}}^{2}=59.46 \%\right)$ and narrow-sense heritability of low magnitude $(21.37 \%)$, indicating difficulties for selection because the effects of environmental variance were also significant.

Phosphorus content in common bean seeds is believed to exhibit quantitative inheritance, because higher effects of environmental variance and the intermediate to low narrow-sense heritability were observed in this study (Table 2). Thus, we expected difficulties in making a selection of the character measured. A more in-depth study of the genetic effects and the number of genes that control phosphorus content could not be carried out in this study as the efficiency of hybridization was low and very low numbers of replications for generations $\mathrm{F}_{2}$ and backcrosses $\left(\mathrm{BCP}_{1}\right.$ and $\left.\mathrm{BCP}_{2}\right)$ were obtained.

Conventional heterosis of $6.69 \%$ and heterobeltiosis of $15.67 \%$ were obtained in the Pérola x Guapo Brilhante hybrid (Table 2). Thus, hybrid vigor was observed for phosphorus content in the common bean seeds and the dominance and superdominance hypotheses should be considered. As the common bean plant is self-fertilizing, heterosis is expected to be reduced by half in each self- 
ND Ribeiro et al.

Table 2. Estimates of means, genetic parameters and prediction of phosphorus content selection gains in the common bean seeds of Pérola x Guapo Brilhante and TPS Nobre x Guapo Brilhante hybrids

\begin{tabular}{|c|c|c|}
\hline \multirow{2}{*}{ Parameters } & \multicolumn{2}{|c|}{ Phosphorus content (g kg-1 of DM) } \\
\hline & Pérola x Guapo Brilhante & TPS Nobre x Guapo Brilhante \\
\hline Mean & 4.29 & 4.53 \\
\hline CVE $(\%)$ & 0.31 & 11.06 \\
\hline Phenotypic variance $\left(\sigma_{\mathrm{P}}^{2}\right)$ & 0.23 & 0.26 \\
\hline Environmental variance $\left(\sigma_{\mathrm{E}}^{2} \mathrm{~F}_{2}\right)$ & 0.04 & 0.10 \\
\hline Genetic variance $\left(\sigma_{\mathrm{G}}^{2}\right)$ & 0.19 & 0.15 \\
\hline Additive variance $\left(\sigma_{\mathrm{A}}^{2}\right)$ & 0.15 & 0.05 \\
\hline Broad-sense heritability $\left(\mathrm{h}_{\mathrm{a}}^{2}\right)$ & 82.69 & 59.46 \\
\hline Narrow-sense heritability $\left(\mathrm{h}_{\mathrm{r}}^{2}\right)$ & 65.54 & 21.37 \\
\hline Heterosis (H \%) & 6.69 & -13.03 \\
\hline Heterobeltiosis $\mathrm{P}_{1}(\mathrm{HT} \%)$ & 15.67 & -5.86 \\
\hline Maximum value in parents & 5.08 & 5.08 \\
\hline Minimum value in parents & 3.94 & 3.81 \\
\hline Maximum value in $F_{2}$ & 5.31 & 5.78 \\
\hline Minimum value in $F_{2}$ & 3.38 & 3.90 \\
\hline Selected plant in $\mathrm{F}_{2}$ & $8,5,7,23,17$ and 24 & $13,14,11,22,21$ and 7 \\
\hline Original mean in $\mathrm{F}_{2}$ & 4.22 & 4.68 \\
\hline Mean of selected plants & 4.83 & 5.33 \\
\hline Selection differential (SD) & 0.61 & 0.65 \\
\hline Selection gain $(\Delta \mathrm{G})$ & 0.40 & 0.14 \\
\hline Selection gain $(\Delta \mathrm{G} \%)$ & 9.47 & 2.97 \\
\hline Predicted mean after the first selection cycle & 4.62 & 4.82 \\
\hline
\end{tabular}

fertilizing generation, and for this reason, the $\mathrm{F}_{3}$ generation may present lower means than that of $\mathrm{F}_{2}$. In view of this, evaluation in advanced generations will be necessary to assess segregation for this character.

In relation to selection gains, assuming retention of $25 \%$ plants with $\mathrm{F}_{2}$ seeds (cotyledons in $\mathrm{F}_{2}$ generation) with the highest phosphorus content, gains of $9.47 \%$ and $2.97 \%$ could be expected, with predicted means of 4.62 and $4.82 \mathrm{~g} \mathrm{~kg}^{-1} \mathrm{DM}$, respectively, after the first selection cycle in the Pérola $x$ Guapo Brilhante and TPS Nobre $x$ Guapo Brilhante hybrids (Table 2). Therefore, early germplasm selection of common bean seeds with high phosphorus content could be effective in the development of common bean cultivars with a high nutritional value that could be used in foods to reduce the risk of phosphorus deficiency and lower the number of cases of malnutrition. This also could contribute to increase grain yield (Silva et al. 2003).

Since it was possible to increase phosphorous content in common bean seeds using genetic improvement, this strategy could have positive impacts on the economics of non-renewable natural resources, on the conservation of the environment and on keeping the population healthy. However, the bioavailability of phosphorous will need to be assessed, since in legumes, this mineral is found mainly in the form of phytic acid, which is very difficult for the human digestive tract to absorb. Phytic acid is considered to be an anti-nutritional factor due to its capacity to form complexes with some minerals, rendering them unavailable and affecting their bioavailability (Cheryan et al. 1980). One of the main physiological functions of phytic acid in the plant is its role as a phosphorous reserve, representing around 60 to $97 \%$ of total phosphorous (Ravindran et al. 1994). This can limit the nutritional quality of diets, especially in Latin America where 8 to $27 \%$ of the phosphorus content necessary to satisfy daily nutritional requirements is obtained by consumption of the common bean (Pennington and Young 1990).

\section{CONCLUSIONS}

There is no maternal effect in the expression of the common bean seeds phosphorous content and early generation narrow-sense heritability of the character is between intermediate and low. It is possible to increase phosphorous content in common bean seeds by $19.17 \%$ using genetic improvement. 


\title{
ACKNOWLEDGEMENTS
}

To the National Council of Technological and Scientific Development (CNPq) and the Rio Grande do Sul Research Support Foundation (FAPERGS) for the grants awarded.

\section{Genética do teor de fósforo em sementes de feijão}

\begin{abstract}
RESUMO - O feijão é uma importante fonte de minerais e de proteína para a nutrição humana. O objetivo desse trabalho foi investigar a existência de efeito materno na expressão do teor de fósforo em sementes de feijão, obter estimativas de herdabilidade em gerações precoces e avaliar o potencial do melhoramento para esta característica. Os cruzamentos dirigidos foram realizados entre as cultivares Pérola x Guapo Brilhante e TPS Nobre x Guapo Brilhante. As gerações $F_{1}, F_{1}$ recíproco, $F_{2}, F_{2}$ recíproco e retrocruzamentos foram obtidas para cada combinação híbrida. O teor de fósforo variou de 3,38 a 5,78 $\mathrm{g} \mathrm{kg}^{-1}$ de matéria seca e nenhum efeito materno significativo foi observado. Herdabilidade em sentido restrito de intermediária $(65,54 \%)$ a baixa (21,37\%) foi observada. Um incremento de 19,17\% foi obtido para o teor de fósforo em sementes de feijão, usando os três genitores testados neste estudo.
\end{abstract}

Palavras-chave: Phaseolus vulgaris L.; efeito materno; herdabilidade; seleção precoce.

\section{REFERENCES}

Barampama Z and Simard RE (1993) Nutrient composition, protein quality and antinutritional factors of some varieties of dry beans (Phaseolus vulgaris) grown in Burundi. Food Chemistry 47: 159-167.

Beebe S, Gonzalez V and Rengifo J (2000) Research on trace minerals in the common bean. Food and Nutrition Bulletin 21: $387-391$

Blair MW, Astudillo C, Grusak MA, Graham R and Beebe SEI (2009) Inheritance of seed iron and zinc concentrations in common bean (Phaseolus vulgaris L.). Molecular Breeding 23: $197-207$.

Carvalho FIF, Silva SA, Kurek AJ and Marchiori VS (2001) Estimativas e implicações da herdabilidade como estratégia de seleção. Editora UFPEL, Pelotas, 98p.

Cheryan M (1980) Phytic acid interaction in food systems. CRC Critical Reviews in Food Science and Nutrition 13: 297335.

Cichy KA, Forster S, Grafton KF and Hosfield GL (2005) Inheritance of seed zinc accumulation in navy bean. Crop Science 45: $864-870$

Cozzolino SMF (2007) Biodisponibilidade de nutrientes. Manole, São Paulo, 992p.

Cruz CD (2006) Programa Genes. Editora UFV, Viçosa, 382p.

Fennema OR (2000) Química de los alimentos. Acribia, Zaragoza, 1272p.
Gelin JR, Forster S, Grafton KF, McClean PE and Rojas-Cifuentes GA (2007) Analysis of seed zinc and other minerals in a recombinant inbred population of navy bean (Phaseolus vulgaris L.). Crop Science 47: 1361-1366.

House WA, Welch RS, Beebe S and Cheng Z (2002) Potential for increasing the amounts of bioavailable zinc in dry beans (Phaseolus vulgaris L.) through plant breeding. Journal of the Science of Food and Agriculture 82: 1452-1457.

Islam FMA, Basford KE, Jara C, Redden RJ and Beebe S (2002) Seed compositional and disease resistance differences among gene pools in cultivated common bean. Genetic Resources and Crop Evolution 49: 285-293.

Jost E, Ribeiro ND, Mazieiro SM, Cerutti T and Rosa DP (2009a) Efeitos gênicos do teor de cálcio em grãos de feijão. Ciência Rural 39: 31-37.

Jost E, Ribeiro ND, Cerutti T, Poersch NL and Mazieiro SM (2009b) Potencial de aumento do teor de ferro em grãos de feijão por melhoramento genético. Bragantia 68: 35-42.

Kathleen ML (1998) Krause: alimentos, nutrição e dietoterapia. Roca, São Paulo, 1179p.

Londero PMG, Ribeiro ND, Jost E, Maziero SM, Cerutti T and Poersch NL (2009) Genética dos teores de fibras insolúvel e solúvel em grãos de feijão. Revista Ceres 56: 150-155.

Mesquita FR, Corrêa AD, Abreu CMP, Lima RAZ and Abreu AF (2007) Linhagens de feijão (Phaseolus vulgaris L.): composição química e digestibilidade protéica. Ciência e Agrotecnologia 31: $1114-1121$. 
ND Ribeiro et al.

Miyazawa M, Pavan MA, Muraoka T, Carmo CAFS and Mello WJ (1999) Análises químicas de tecido vegetal. In Silva FC (ed) Manual de análises químicas de solos, plantas e fertilizantes. Embrapa Solos, Brasília, p. 171-223.

Moraghan JT, Padilha J, Etchevers JD, Grafton K and AcostaGallegos JA (2002) Iron accumulation in seed of common bean Plant and Soil 246: 175-183.

Pennington JAT and Young B (1990) Sodium, potassium, calcium, phosphorus and magnesium in foods from the United States total diet study. Journal of Food Composition and Analysis 3: $145-165$.

Peternelli LA and Borém A (1999) Hibridação em feijão. In Borém A (ed) Hibridação artificial em plantas. Editora UFV, Viçosa, p. 269-294.

Ramalho MAP, Santos JB and Pinto CBP (2008) Genética na agropecuária. $4^{\text {th }}$ ed, Editora UFLA, Lavras, 463p.
Ravindran V, Ravindran G and Sivalogan S (1994) Total and phytate phosphorus contents of various foods and feedstuffs of plant origin. Food Chemistry 50: 133-136.

Sfredo GJ, Borkert CM, Lantamann AF, Meyer MC, Mandarino JMG and Oliveira MCN (1997) Molibdênio e cobalto na cultura da soja. Embrapa Cnpso, Londrina (Circular técnica, 16).

Silva RJS and Vahl LC (2002) Resposta do feijoeiro a adubação fosfatada num neossolo litólico distrófico da região sul do Rio Grande do Sul. Revista Brasileira de Agrociência 8: 129. 132.

Silva RJS, Vahl LC and Peske ST (2003) Rendimento de grãos no feijoeiro em função dos teores de fósforo nas sementes. Revista Brasileira de Agrociência 9: 247-250.

Warner JN (1952) A method for estimating heritability. Agronomy Journal 44: 427-430. 